\title{
Effect of essential oils on ruminal fermentation and lactation performance of dairy cows
}

\author{
J. A. Tekippe, ${ }^{*}$ R. Tacoma, ${ }^{*}$ A. N. Hristov, ${ }^{* 1}$ C. Lee, ${ }^{*}$ J. Oh, ${ }^{*}$ K. S. Heyler, ${ }^{*}$ T. W. Cassidy, ${ }^{*}$ \\ G. A. Varga, ${ }^{*}$ and D. Bravot \\ *Department of Animal Science, The Pennsylvania State University, University Park 16802 \\ †Pancosma, 1218 Geneva, Switzerland
}

\section{ABSTRACT}

Three experiments (Exp.) were conducted to study the effects of dietary addition of an essential oil product (EO) based on eugenol and cinnamaldehyde (0, control, or $525 \mathrm{mg} / \mathrm{d}$ of Xtract 6965; Pancosma SA, Geneva, Switzerland) on ruminal fermentation, total-tract digestibility, manure gas emissions, $\mathrm{N}$ losses, and dairy cow performance. In Exp. 1 and 3, the EO supplement was added to the vitamin-mineral premix. In Exp. 2, EO was top-dressed. Experiments 1 and 2 were crossover designs with 20 multiparous Holstein cows each (including 4 and 8 ruminally cannulated cows, respectively) and consisted of two 28-d periods. Intake of dry matter did not differ between treatments. Most ruminal fermentation parameters were unaffected by EO. Concentrations of ammonia (Exp. 1), isobutyrate (Exp. 1 and 2), and isovalerate (Exp. 1) were increased by EO compared with the control. Apparent total-tract digestibility of nutrients was similar between treatments, except total-tract digestibility of neutral-detergent fiber, which was increased or tended to be increased by EO in Exp. 1 and 2. Manure emissions of ammonia and methane were unaffected by EO. Blood plasma and milk urea- $\mathrm{N}$ concentrations and urinary $\mathrm{N}$ losses were increased by EO compared with the control in Exp. 1, but not in Exp. 2. Average milk yield, 3.5\% fatcorrected milk yield, and milk fat, protein, and lactose concentrations were unaffected by treatment. Urinary excretion of purine derivatives, a marker for microbial protein production in the rumen, was greater in cows receiving the EO diet in Exp. 1, but not in Exp. 2. In Exp. 3, 120 Holstein cows were grouped in pens of 20 cows/pen in a 12-wk experiment to study production effects of EO. Dry matter intake, milk yield (a trend for a slight decrease with EO), milk components, milk urea $\mathrm{N}$, and feed efficiency were similar between treatments. Results from these studies indicate that supplementing

Received June 12, 2013.

Accepted August 26, 2013.

${ }^{1}$ Corresponding author: anh13@psu.edu dairy cows with $525 \mathrm{mg} / \mathrm{d}$ of Xtract 6965 had moderate effects on ruminal fermentation, but consistently increased ruminal isobutyrate concentration and tended to increase total-tract digestibility of neutral-detergent fiber. Under the conditions of these experiments, Xtract 6965 fed at $525 \mathrm{mg} / \mathrm{d}$ did not affect milk production or composition.

Key words: essential oil, rumen fermentation, milk production, dairy cow

\section{INTRODUCTION}

Essential oils (EO) are phytochemicals with a wide range of antimicrobial activities (Chao and Young, 2000). Interest in their use as feed supplements in animal nutrition has been heightened in recent years because of the emphasis on the use of natural compounds as alternatives to feed antibiotics in animal production (Wallace, 2004).

Calsamiglia et al. (2007) compiled an extensive review of the literature and concluded that EO may inhibit deamination of $\mathrm{AA}$ and methanogenesis and shift fermentation toward propionate and butyrate in the rumen. Most experiments with EO, however, have been conducted in vitro. Extrapolation of results from in vitro experiments to in vivo conditions has limitations (Hristov et al., 2012). Although in vitro experiments are useful in screening EO and their components for antimicrobial activity and predicting adequate concentrations, the true value of these phytochemicals for altering rumen microbial fermentation and animal production must be assessed in vivo. Increases in ruminal true OM and N digestibility (Yang et al., 2007), total-tract ADF and starch digestibility (Benchaar et al., 2006), and DMI, milk yield, and milk fat yield (Kung et al., 2008) in dairy cows have been reported with various EO compounds or commercial products. Responses to EO, however, are highly variable. For example, Tassoul and Shaver (2009) reported no effect on milk production and depressed DMI with the same EO product that resulted in increased milk yield in the study of Kung et al. (2008). This variability in 
animal responses to EO is not surprising and is a result of a range of factors, including EO source and active ingredient composition, application rates, experimental conditions, and so on (Benchaar et al., 2009).

The objectives of this series of experiments were to investigate the effects of an EO product, Xtract 6965 (containing eugenol and cinnamaldehyde; Pancosma SA, Geneva, Switzerland), on ruminal fermentation, digestibility, and performance of lactating dairy cows. Our hypothesis was that the inclusion of Xtract 6965 would have positive effects on ruminal fermentation and digestibility that may lead to improved animal performance.

\section{MATERIALS AND METHODS}

\section{Experimental Design and Treatment}

All experiments were conducted under the approval of The Pennsylvania State University Animal Care and Use Committee (IACUC no. 30165, 40049, and 29566; experiments 1,2 , and 3 , respectively).

\section{Experiments 1 and 2}

Experiments (Exp.) 1 and 2 were crossover design trials with 2 groups and 2 experimental periods and were conducted at the tie-stall facility of the Pennsylvania State University's Dairy Center. Experiment 1 was conducted in 2009 and Exp. 2 in 2012. Each experimental period lasted $28 \mathrm{~d}$, with $21 \mathrm{~d}$ for adaptation and $7 \mathrm{~d}$ for data collection and sampling. Each experiment was conducted with 20 multiparous Holstein dairy cows averaging (Exp. 1) $2.6 \pm 0.18$ lactations, $62 \pm 5.5$ DIM, $46 \pm 1.6 \mathrm{~kg} / \mathrm{d}$ of milk yield, and $656 \pm 16.0 \mathrm{~kg}$ of BW and (Exp. 2) $2.4 \pm 0.25$ lactations, $84 \pm 11.5$ DIM, $42 \pm 1.7 \mathrm{~kg} / \mathrm{d}$ of milk yield, and $658 \pm 27.2 \mathrm{~kg}$ of BW at the beginning of the trials. In Exp. 1, 4 cows ( 2 per treatment in each experimental period) and in Exp. 2, 8 cows (4 per treatment in each experimental period) were fitted with soft plastic ruminal cannulas (10.2-cm internal diameter; Bar Diamond Inc., Parma, ID). Cows received a TMR containing either the control diet (Table 1) or the control diet supplemented with Xtract 6965 (EO treatment) to provide $525 \mathrm{mg}$ of Xtract 6965/cow per day. The active ingredients of Xtract 6965 (Pancosma SA) are eugenol (28\%) and cinnamaldehyde (17\%). In Exp. 1, Xtract 6965 was mixed with the mineral-vitamin premix by the premix manufacturer (Cargill Animal Nutrition, Cargill Inc., Roaring Spring, PA) and then mixed with the TMR; in Exp. 2, Xtract 6965 was premixed with a small amount (approximately $100 \mathrm{~g}$ ) of the bakery byproduct meal and then top-dressed and mixed with a portion of the TMR before feeding. To ensure delivery of Xtract 6965 , the bakery byproduct premix was analyzed for cinnamaldehyde and eugenol using gas-liquid chromatography with a flame-ionization detector (Agilent GLC model 6890N; Agilent Technologies Inc., Santa Clara CA). Standards were trans-cinnamaldehyde and eugenol (Sigma-Aldrich Corp., St. Louis, MO). The GLC column was HP-5MS UI $(30 \mathrm{~m} \times 0.25 \mathrm{~mm} \times$ $0.25 \mathrm{~m}$; Agilent Technologies Inc.); injection was $1 \mu \mathrm{L}$, split $1 / 50$; inlet temperature was $250^{\circ} \mathrm{C}$; detector was set at $300^{\circ} \mathrm{C}, 40 \mathrm{~mL} / \mathrm{min}_{2}, 400 \mathrm{~mL} / \mathrm{min}$ air, $100 \mathrm{~Hz}$; and gas carrier was He at $1.4 \mathrm{~mL} / \mathrm{min}$. Recovery of the compounds in the premix was $83 \%$ for cinnamaldehyde and $99 \%$ for eugenol.

Feeding was once daily at approximately $0800 \mathrm{~h}$. Feed was pushed up to the cows approximately 4 to 6 times per day. Diets were formulated (NRC, 2001) to meet the requirements of the cows based on DMI and milk production immediately before the trial and were fed ad libitum to achieve approximately $5 \%$ refusals. In Exp. 1, the basal diet exceeded by about $3 \mathrm{Mcal} / \mathrm{d}$ the $\mathrm{NE}_{\mathrm{L}}$ requirements of the control group of cows, but was on average $148 \mathrm{~g} / \mathrm{d}$ (or 5\%) deficient in MP (according to NRC, 2001 and based on DMI and milk yield during the trial). In Exp. 2, the diet supplied 3.5 Mcal $\mathrm{NE}_{\mathrm{L}} / \mathrm{d}$ in excess of the requirements of the control cows and was about $8 \%$ (219 g/d) MP-deficient. Cows had access to fresh water throughout the duration of the trial. Milking was twice daily at about 0530 and 1730 h. Cows received recombinant bST (Posilac, Elanco Co., Greenfield, IN; $500 \mathrm{mg} / \mathrm{cow}$, i.m.) at 14-d intervals beginning at 63 DIM.

\section{Exp. 3}

This experiment was conducted in 2009, simultaneously with Exp. 1, and was $84 \mathrm{~d}$ in duration, including a 2 -wk covariate period [during which all cows received the control diet, and DMI, milk yield, and milk composition (1 sample during wk 2) data were collected], a 2-wk adaptation period, and an 8-wk experimental period. The haylage and corn silage sources were changed approximately 8 wk into the experiment, which necessitated minor dietary changes. The nutrient composition of the diet, however, remained relatively stable throughout the experiment (Table 2). The basal diet was formulated (NRC, 2001) to meet the requirements of the cows based on DMI and milk production before the trial. During the trial, the diet exceeded the $\mathrm{NE}_{\mathrm{L}}$ requirements of the control cows by about $7 \mathrm{Mcal} / \mathrm{d}$ and the MP requirements by about $119 \mathrm{~g} / \mathrm{d}$ (according to NRC, 2001 and based on DMI and milk yield during the trial). One hundred twenty multiparous $(\mathrm{n}=64)$ and primiparous $(\mathrm{n}=56)$ Holstein cows were used in the experiment. Average BW 
Table 1. Ingredient and chemical composition (\% of DM unless noted otherwise) of the basal diet fed to dairy cows in experiments (Exp.) 1 and 2

\begin{tabular}{|c|c|c|}
\hline Item & Exp. 1 & Exp. 2 \\
\hline \multicolumn{3}{|l|}{ Ingredient composition } \\
\hline Corn silage ${ }^{1}$ & 34.0 & 38.9 \\
\hline Alfalfa haylage $^{2}$ & 15.9 & 15.6 \\
\hline Grass hay/straw & 4.4 & - \\
\hline Corn grain ${ }^{3}$ & 10.6 & 10.6 \\
\hline Whole soybeans, heated & 8.0 & 7.8 \\
\hline Canola meal & 6.1 & 8.9 \\
\hline Bakery byproduct meal ${ }^{4}$ & 7.3 & 5.9 \\
\hline Cottonseed hulls & 5.8 & 5.2 \\
\hline Sugar blend ${ }^{5}$ & 4.2 & 4.1 \\
\hline Mineral-vitamin premix ${ }^{6}$ & 3.3 & 2.8 \\
\hline Optigen $^{7}$ & 0.4 & - \\
\hline Salt & - & 0.2 \\
\hline \multicolumn{3}{|c|}{ Analyzed chemical composition } \\
\hline DM, $\%$ & 49.7 & 51.9 \\
\hline $\mathrm{CP}$ & 15.5 & 15.1 \\
\hline Soluble protein, $\%$ of CP & 5.0 & 5.6 \\
\hline $\mathrm{ADF}$ & 22.5 & 21.7 \\
\hline NDF & 32.9 & 30.7 \\
\hline $\mathrm{NFC}^{8}$ & 40.3 & 45.0 \\
\hline $\mathrm{TNC}^{9}$ & 32.8 & -11 \\
\hline $\mathrm{NE}_{\mathrm{J}}{ }^{10} \mathrm{Mcal} / \mathrm{kg}$ & 1.61 & 1.65 \\
\hline $\mathrm{Ca}$ & 0.92 & 0.96 \\
\hline $\mathrm{P}$ & 0.32 & 0.38 \\
\hline $\mathrm{Mg}$ & 0.34 & 0.36 \\
\hline $\mathrm{K}$ & 1.32 & 1.26 \\
\hline $\mathrm{Na}$ & 0.46 & 0.20 \\
\hline S & 0.22 & -11 \\
\hline $\mathrm{Fe}, \mathrm{mg} / \mathrm{kg}$ & 141 & 282 \\
\hline $\mathrm{Zn}, \mathrm{mg} / \mathrm{kg}$ & 75 & 72 \\
\hline $\mathrm{Cu}, \mathrm{mg} / \mathrm{kg}$ & 19 & 23 \\
\hline $\mathrm{Mn}, \mathrm{mg} / \mathrm{kg}$ & 70 & 82 \\
\hline
\end{tabular}

${ }^{1}$ In Exp. 1, contained 32.3\% DM and (DM basis) 6.8\% CP, 25.1\% ADF, 40.0\% NDF, 48.4\% NFC, 3.3\% fat, $2.8 \%$ ash, $0.15 \% \mathrm{Ca}, 0.21 \% \mathrm{P}$, and $1.63 \mathrm{Mcal} / \mathrm{kg}$ of NE . In Exp. 2, contained $32.6 \% \mathrm{DM}$ and (DM basis) $8.1 \%$ CP, $21.0 \%$ ADF, $36.7 \% \mathrm{NDF}, 50.5 \% \mathrm{NFC}, 3.0 \%$ fat, $2.9 \%$ ash, $0.19 \% \mathrm{Ca}, 0.27 \% \mathrm{P}$, and $1.56 \mathrm{Mcal} / \mathrm{kg}$ of $\mathrm{NE}_{\mathrm{L}}$. ${ }^{2}$ In Exp. 1, contained 47.3\% DM and (DM basis) $20.4 \%$ CP, 30.6\% ADF, 39.7\% NDF, $31.2 \%$ NFC, $2.8 \%$ fat, $9.7 \%$ ash, $1.22 \% \mathrm{Ca}, 0.30 \% \mathrm{P}$, and $1.50 \mathrm{Mcal} / \mathrm{kg}$ of $\mathrm{NE}_{\mathrm{L}}$. In Exp. 2, contained $49.8 \% \mathrm{DM}$ and (DM basis) $19.3 \%$ $\mathrm{CP}, 37.6 \% \mathrm{ADF}, 43.6 \% \mathrm{NDF}, 27.8 \% \mathrm{NFC}, 3.1 \%$ fat, $8.9 \%$ ash, $1.19 \% \mathrm{Ca}, 0.26 \% \mathrm{P}$, and $1.32 \mathrm{Mcal} / \mathrm{kg}$ of $\mathrm{NE}_{\mathrm{L}}$.

${ }^{3}$ Exp. 1: 50:50 blend of ground and cracked dry corn grain; Exp. 2: ground corn grain.

${ }^{4}$ Dried bakery byproduct (Bakery Feeds, Honey Brook, PA) contained (DM basis) 9\% CP, $8 \%$ ether extract, and $5 \%$ crude fiber.

${ }^{5}$ Sugar blend (Westway Feed Products, Tomball, TX) contained (DM basis) 3.9\% CP and 66\% total sugar.

${ }^{6}$ In Exp. 1, the premix contained (\%, as-is basis) trace mineral mix, 0.88; $\mathrm{MgO}(54 \% \mathrm{Mg}), 8.3 ; \mathrm{NaCl}, 6.4$; vitamin ADE premix, 1.73; limestone, 35.8; selenium premix, 1.09; and dry corn distiller grains with solubles, 45.8. Composition: Ca, 14.1\%; P, 0.35\%; Mg, 4.58\%, K, 0.41\%; S, 0.31\%; Mn, $1,071 \mathrm{mg} / \mathrm{kg} ; \mathrm{Cu}, 358 \mathrm{mg} / \mathrm{kg}$; Zn, $1,085 \mathrm{mg} / \mathrm{kg} ; \mathrm{Fe}, 181 \mathrm{mg} / \mathrm{kg}$; Se, $6.67 \mathrm{mg} / \mathrm{kg}$; Co, $5.4 \mathrm{mg} / \mathrm{kg}$; I, $13.4 \mathrm{mg} / \mathrm{kg}$; vitamin A, 262,101 IU/ kg; vitamin D, 65,421 IU/kg; and vitamin E, 1,971 IU/kg. In Exp. 2, the premix contained (\%, as-is basis) trace mineral mix, 0.88; $\mathrm{MgO}(54 \% \mathrm{Mg}), 8.3 ; \mathrm{NaCl}, 6.4$; vitamin ADE premix, 0.99; vitamin E premix, 0.74; limestone, 35.8; selenium premix, 1.09; and dry corn distiller grains with solubles, 45.8. Composition: Ca, 14.1\%; P, 0.35\%; Mg, 4.58\%, K, 0.41\%; S, 0.30\%; Mn, 1,071 mg/kg; Cu, $357 \mathrm{mg} / \mathrm{kg} ; \mathrm{Zn}, 1,085 \mathrm{mg} / \mathrm{kg} ; \mathrm{Fe}, 181 \mathrm{mg} / \mathrm{kg}$, Se, $6.67 \mathrm{mg} / \mathrm{kg}$; vitamin A, 262,101 IU/kg; vitamin D, 65,421 IU/kg; and vitamin E, 1,971 IU/kg.

${ }^{7}$ Nonprotein nitrogen source $(243.2 \%$ CP, DM basis) from Alltech Inc. (Nicholasville, KY).

${ }^{8} \mathrm{NFC}=100-[\% \mathrm{CP}+(\% \mathrm{NDF}-\mathrm{NDFCP})+\%$ ash $+\%$ fat $]$.

${ }^{9}$ Total nonstructural carbohydrates.

${ }^{10}$ Estimated based on NRC (2001).

${ }^{11}$ Not analyzed in Exp. 2.

of the cows was $680 \pm 16 \mathrm{~kg}$. Cows were blocked into 3 blocks based on parity (2.2 \pm 0.18 lactations), DIM (190 $\pm 15.5 \mathrm{~d})$, and milk yield $(41 \pm 1.6 \mathrm{~kg} / \mathrm{d})$ before the trial. Cows within block were randomly assigned to 1 of 2 treatments (see below). The freestall barn where this experiment took place had 6 pens, 3 on each side of the barn. Cows within treatment were randomly assigned to 1 of 3 pens (i.e., 20 cows/pen), and then pens on one side of the barn were randomly allocated to one treatment and pens on the others side of the barn to the other 
treatment. Pens (3 per treatment) were assigned to 1 of the following 2 treatments: TMR containing control mineral-vitamin premix or TMR containing mineralvitamin premix supplemented (by the manufacturer as in Exp. 1) with Xtract 6965 (EO treatment) to provide $525 \mathrm{mg}$ product/cow per day. The trial was conducted in the freestall facility of the Pennsylvania State University's Dairy Center and the experimental unit was the pen $(\mathrm{n}=3)$. Feeding was once daily at approximately $0500 \mathrm{~h}$, with feed being pushed up 4 to 6 times per day. Cows were fed ad libitum to achieve approximately $5 \%$ refusals and had free access to fresh water throughout the duration of the trial. Cows were milked daily at approximately 0600 and $1800 \mathrm{~h}$ and received recombinant bST (Posilac, Elanco Co.; $500 \mathrm{mg} /$ cow, i.m.) as in Exp. 1 and 2.

\section{Measurements and Sample Collections}

Exp. 1 and 2. Feed intake was recorded daily, with diet and refusal samples collected twice weekly and composited by week. Diet and refusal samples were dried for $48 \mathrm{~h}$ at $65^{\circ} \mathrm{C}$ in a forced-air oven and then ground in a Wiley mill (A. H. Thomas, Philadelphia, PA) through a 1-mm screen. All TMR and refusal samples were composited by period. Composited samples were pulverized at $30 \mathrm{~Hz} / \mathrm{s}$ for 2 min using a Mixer Mill MM 200 (Retsch GmbH, Haan, Germany) for N analysis. Forages were sampled weekly and dried in a microwave oven to determine DM. Weekly changes were made in the TMR, if changes occurred in forage DM.

In Exp. 1, 6 spot urine (approximately $300 \mathrm{~mL} / \mathrm{sam}-$ ple) and fecal (approximately $400 \mathrm{~g} /$ sample) samples were collected on 2 consecutive days at $1900 \mathrm{~h}(\mathrm{~d} 1)$ and 0300 and $1100 \mathrm{~h} \mathrm{(d} \mathrm{2)} \mathrm{during} \mathrm{wk} 4$ of each experimental period. In Exp. 2, 8 urine and fecal samples were collected on 3 consecutive days of each experimental period at 1000, 1600, and $2200 \mathrm{~h} \mathrm{(d} \mathrm{1);0400,} \mathrm{1300,}$ and $1900 \mathrm{~h} \mathrm{(d} \mathrm{2);} \mathrm{and} 0100$ and $0800 \mathrm{~h} \mathrm{(d} \mathrm{3).} \mathrm{Urine}$ samples were collected by massaging the vulva. Fecal samples were collected by stimulating defecation, or from the rectum. Fecal samples were oven-dried at $65^{\circ} \mathrm{C}$ and composited per cow and period on an equal DM basis. Fresh urine and fecal samples from each cow were composited on a wet basis by experimental period and frozen immediately at $-20^{\circ} \mathrm{C}$ for later analysis of the ammonia and methane emitting potential of manure.

Cows were weighed daily using the Afifarm 3.04E scale system (S.A.E. Afikim, Rehovot, Israel) while they exited the milk parlor. Body weight data for 3 consecutive days at the beginning and end of the trial and at the start of the second experimental period of each trial were used in the statistical analysis.

Milk production was recorded daily in both experiments. Milk composition samples were collected from
Table 2. Ingredient and chemical composition (\% of DM unless noted otherwise) of the basal diet fed to dairy cows in experiment 3

\begin{tabular}{|c|c|c|}
\hline Item & $\begin{array}{l}\text { January } 28 \text { to } \\
\text { March 26, } 2009\end{array}$ & $\begin{array}{l}\text { March } 27 \text { to } \\
\text { May } 6,2009\end{array}$ \\
\hline \multicolumn{3}{|l|}{ Ingredient composition } \\
\hline Corn silage $\mathrm{e}^{1}$ & 34.0 & 34.0 \\
\hline Alfalfa haylage ${ }^{2}$ & 15.9 & 15.9 \\
\hline Grass hay/straw & 4.4 & 4.4 \\
\hline Corn grain ${ }^{3}$ & 10.6 & 11.2 \\
\hline Whole soybeans, heated & 8.0 & 7.7 \\
\hline Canola meal & 6.1 & 5.8 \\
\hline Bakery byproduct meal $^{4}$ & 7.3 & 7.3 \\
\hline Cottonseed hulls & 5.8 & 5.8 \\
\hline Sugar blend ${ }^{5}$ & 4.2 & 4.2 \\
\hline Mineral/vitamin premix $^{6}$ & 3.3 & 3.3 \\
\hline Optigen ${ }^{7}$ & 0.4 & 0.4 \\
\hline \multicolumn{3}{|c|}{ Analyzed chemical composition } \\
\hline $\mathrm{DM}, \%$ & 49.7 & 48.6 \\
\hline $\mathrm{CP}$ & 15.5 & 15.7 \\
\hline Soluble protein, \% CP & 5.0 & 5.3 \\
\hline $\mathrm{ADF}$ & 22.6 & 22.6 \\
\hline $\mathrm{NDF}$ & 32.9 & 32.9 \\
\hline $\mathrm{NFC}^{8}$ & 40.3 & 39.5 \\
\hline $\mathrm{NE}_{\mathrm{L}},{ }^{9} \mathrm{Mcal} / \mathrm{kg}$ & 1.65 & 1.65 \\
\hline $\mathrm{Ca}$ & 0.91 & 0.92 \\
\hline $\mathrm{P}$ & 0.32 & 0.32 \\
\hline $\mathrm{Mg}$ & 0.33 & 0.34 \\
\hline $\mathrm{K}$ & 1.32 & 1.32 \\
\hline $\mathrm{Na}$ & 0.42 & 0.42 \\
\hline $\mathrm{S}$ & 0.23 & 0.33 \\
\hline $\mathrm{Fe}, \mathrm{mg} / \mathrm{kg}$ & 141.3 & 136.5 \\
\hline $\mathrm{Zn}, \mathrm{mg} / \mathrm{kg}$ & 75.1 & 75.0 \\
\hline $\mathrm{Cu}, \mathrm{mg} / \mathrm{kg}$ & 18.6 & 19.5 \\
\hline $\mathrm{Mn}, \mathrm{mg} / \mathrm{kg}$ & 69.6 & 69.3 \\
\hline
\end{tabular}

${ }^{1}$ In the first period, contained $32.2 \% \mathrm{DM}$ and (DM basis) $6.8 \% \mathrm{CP}$ $25.1 \%$ ADF $, 40.0 \% \mathrm{NDF}, 48.4 \% \mathrm{NFC}, 3.3 \%$ fat, $2.8 \%$ ash, $0.15 \% \mathrm{Ca}$, $0.21 \% \mathrm{P}$, and $1.63 \mathrm{Mcal} / \mathrm{kg}$ of $\mathrm{NE}_{\mathrm{L}}$. In the second period, contained $36.5 \% \mathrm{DM}$ and (DM basis) $7.0 \% \mathrm{CP}, 24.8 \% \mathrm{ADF}, 40.0 \% \mathrm{NDF}, 48.1 \%$ NFC, $3.3 \%$ fat, $2.7 \%$ ash, $0.15 \% \mathrm{Ca}, 0.22 \% \mathrm{P}$, and $1.63 \mathrm{Mcal} / \mathrm{kg}$ of $\mathrm{NE}_{\mathrm{L}}$.

${ }^{2}$ In the first period, contained $47.3 \% \mathrm{DM}$ and (DM basis) $20.4 \% \mathrm{CP}$, $30.6 \%$ ADF, $39.7 \%$ NDF, $31.2 \%$ NFC, $2.8 \%$ fat, $9.7 \%$ ash, $1.22 \% \mathrm{Ca}$ $0.30 \% \mathrm{P}$, and $1.50 \mathrm{Mcal} / \mathrm{kg}$ of $\mathrm{NE}_{\mathrm{L}}$. In the second period, contained $47.0 \% \mathrm{DM}$ and (DM basis) 23.0\% CP, 35.1\% ADF, 38.4\% NDF, $27.0 \%$ NFC, $3.5 \%$ fat, $10.3 \%$ ash, $1.61 \% \mathrm{Ca}, 0.34 \% \mathrm{P}$, and $1.41 \mathrm{Mcal} / \mathrm{kg}$ of $\mathrm{NE}_{\mathrm{L}}$.

${ }^{3}$ A 50:50 blend of ground and cracked dry corn grain.

${ }^{4}$ Dried bakery byproduct (Bakery Feeds, Honey Brook, PA) contained (DM basis) $9 \%$ CP, $8 \%$ ether extract, and $5 \%$ crude fiber.

${ }^{5}$ Sugar blend (Westway Feed Products, Tomball, TX) contained (DM basis) $3.9 \% \mathrm{CP}$ and $66 \%$ total sugar.

${ }^{6}$ Composition of the mineral-vitamin premix was as for Exp. 1 (Table 1).

${ }^{7}$ Nonprotein nitrogen source $(243.2 \%$ CP, DM basis) from Alltech Inc. (Nicholasville, KY).

${ }^{8} \mathrm{NFC}=100-[\% \mathrm{CP}+(\% \mathrm{NDF}-\mathrm{NDFCP})+\%$ ash $+\%$ fat $]$.

${ }^{9}$ Estimated based on NRC (2001).

consecutive a.m. and p.m. milkings, 3 times during wk 4 of each experiment. Morning and evening samples were analyzed separately so milk component concentration and yield could be weighted for a.m. and p.m. milk yields. Samples were preserved using 2-bromo2-nitropropane-1,3 diol. 
Blood samples were collected from the tail vein or artery $2 \mathrm{~h}$ after feeding on 2 consecutive days during wk 4 of each experimental period in Exp. 1. In Exp. 2, blood was collected from 4 cows on each treatment in period 2 only.

Whole ruminal contents samples (from the cannulated cows; 4 in Exp. 1 and 8 in Exp. 2) were collected on 2 consecutive days during wk 4 of each experimental period at 2, 4, and $6 \mathrm{~h}$ after feeding.

Exp. 3. Feed intake was recorded for each pen using a TMR tracker program (Digi Star EZ 3500V, Digi Star, Fort Atkinson, WI). Refusals were collected daily and the weight was recorded. Individual feeds, TMR, and refusals were sampled twice weekly and composited on a weekly basis for later analysis. Individual forages were sampled once a week. Concentrate feeds were sampled at wk 3,6,9, and 12 of the trial and composited for further analyses. Diet and refusal samples were dried for $48 \mathrm{~h}$ at $65^{\circ} \mathrm{C}$ in a forced-air oven and then ground in a Wiley mill (A. H. Thomas) through a 1-mm screen. Haylage source changed from upright silo to bag, and corn silage changed from bunker to bag at the beginning of wk 9 of the trial. Diet and refusal samples were composited into subgroups based on forage sources and analyzed separately (Table 2).

Daily milk yields and pen DMI were recorded throughout the duration of the trial. Data for wk 5 through 12 were used in the statistical analysis. Body weight data were not collected in this experiment. Milk samples were collected from the p.m. and a.m. milkings on the last day of the covariate period and during wk $4,6,9$, and 12 of the trial. Samples were preserved using 2-bromo-2-nitropropane-1,3 diol and analyzed for composition as in Exp. 1 and 2. Morning and evening samples were analyzed separately so milk component concentration and yield could be weighted for a.m. and p.m. milk yields.

\section{Analytical Procedures}

Dry matter intake was calculated by adjusting daily as-fed feed intake to DM percentage of the weekly diet and refusal composited samples. Diet, refusals, and fecal composited samples (Exp. 1 and 2) were analyzed for NDF and ADF using Ankom A200 apparatus (Ankom Technology, Macedon, NY) according to Van Soest et al. (1991) with heat-stable amylase (Ankom Technology) and sodium sulfite (Fisher Scientific, Waltham, MA) used in the NDF procedure. Nitrogen content for diet, refusals, feces, and urine (Exp. 1 and 2) were analyzed on a Costech ECS 4010 C/N/S elemental analyzer (Costech Analytical Technologies Inc., Valencia, CA) and multiplied by 6.25 to obtain CP. Total nonstructural carbohydrates were analyzed in fecal and diet samples that were reground to pass through a $0.5-\mathrm{mm}$ screen, using a procedure described by Smith (1981) with the modification to use potassium ferricyanide solution as a colorimetric indicator. Indigestible NDF was used as a digestibility marker (Schneider and Flatt, 1975) and was analyzed following a procedure described by Huhtanen et al. (1994; 288-h in situ incubation) with the modification that $25-\mu \mathrm{m}$ porosity filter bags (Ankom Technology) were used. Bag and residues were then analyzed for NDF. Diet and fecal samples were ashed for $4 \mathrm{~h}$ at $600^{\circ} \mathrm{C}$ for $\mathrm{OM}$ determination. In Exp. 3, TMR samples were analyzed for DM, CP, ADF, NDF, ash, soluble protein, NFC, and $\mathrm{NE}_{\mathrm{L}}$ by Dairy One Forage Laboratory (Ithaca, NY) using wet chemistry methods.

Rumen samples were processed and analyzed for rumen fermentation variables $(\mathrm{pH}, \mathrm{VFA}$, ammonia, total free AA, and polysaccharide-degrading enzymatic activities) and protozoal counts in Exp. 1 and pH, VFA, and ammonia in Exp. 2) as described elsewhere (Hristov et al., 2011).

Urine samples were acidified using $2 \mathrm{M} \mathrm{H}_{2} \mathrm{SO}_{4}$, processed, composited per cow and period, and stored frozen for analysis of allantoin, uric acid, urea $\mathrm{N}$, and creatinine as described elsewhere (Lee et al., 2011). Creatinine was used as a marker to estimate urine volume and excretion of urinary $\mathrm{N}$ and purine derivatives (PD; allantoin and uric acid). Blood was processed and analyzed for plasma urea N (PUN) as described previously (Lee et al., 2011).

Milk samples were analyzed for fat, protein, lactose, SCC, and MUN (Pennsylvania DHIA, University Park). Fat, true protein, lactose, and MUN were determined using infrared spectroscopic method (method 927.16; AOAC International, 2005; MilkoScan 4000; Foss Electric, Hillerød, Denmark).

The ammonia and methane emitting potential of manure samples from Exp. 1 were analyzed according to Lee et al. (2012)

\section{Statistical Analysis}

All data were analyzed using the MIXED procedure of SAS (SAS Institute Inc., Cary, NC). Cow was the experimental unit in Exp. 1 and 2 (i.e., 20 experimental units). In these 2 experiments, intake, digestibility, rumen fermentation data (except $\mathrm{pH}, \mathrm{VFA}$, and ammonia), urinary excretions, and milk composition data were analyzed assuming a crossover design. Milk composition data collected during each experimental period were averaged per cow; the average values and average milk yield and DMI during the last week of each experimental period were used in the statistical analysis and to calculate FCM, FCM feed efficiency, milk $\mathrm{NE}_{\mathrm{L}}$, milk 
$\mathrm{NE}_{\mathrm{L}}$ feed efficiency, and milk fat, protein, and lactose yields. The model used was

$$
\mathrm{Y}_{\mathrm{ijkl}}=\mu+\mathrm{G}_{\mathrm{i}}+\mathrm{C}(\mathrm{G})_{\mathrm{ij}}+\mathrm{P}_{\mathrm{k}}+\mathrm{T}_{\mathrm{l}}+\mathrm{e}_{\mathrm{ijk} \mathrm{k}},
$$

where $Y_{i j k l}$ is the dependent variable, $\mu$ is the overall mean, $G_{i}$ is the group, $C(G)_{i j}$ is cow within group, $P_{k}$ is the kth experimental period, $\mathrm{T}_{1}$ is the lth treatment, with the error term $\mathrm{e}_{\mathrm{ijkl}}$ assumed to be normally distributed with mean $=0$ and constant variance. Group and cow within group were random effects and all others were fixed. Dry matter intake, milk yield, and feed efficiency data from wk 4 of each experimental period and rumen $\mathrm{pH}, \mathrm{VFA}$, and ammonia data were analyzed as repeated measures assuming an autoregressive firstorder $[\operatorname{AR}(1)]$ covariance structure. The model was similar to the above model with additional terms for time (day) and treatment $\times$ time interaction. To test the effect of parity, parity and the parity $\times$ treatment interaction were included in the model for DMI and milk yield. In both cases, the interaction parity $\times$ treatment was not significant $(P=0.50$ to 0.56$)$; therefore, both terms were removed from the final models.

Pen was the experimental unit in Exp. 3 (i.e., 3 experimental units). Dry matter intake, milk yield, and feed efficiency data were analyzed as repeated measures assuming an $\operatorname{AR}(1)$ covariance structure. The model included pen, time (day), treatment, pen $\times$ treatment and day $\times$ treatment interactions, and a term for the covariate measurement. Pen and pen $\times$ treatment were random effects, whereas all others were fixed. Milk composition data were averaged and the average values were used to calculate milk fat and protein yields, FCM and FCM feed efficiency, and in the statistical analysis. The model included pen, treatment, pen $\times$ treatment, and a term for the covariate measurement. Pen and pen $x$ treatment were random effects.

Cumulative ammonia and methane emissions from manure data were fitted to a quadratic model: $(\mathrm{a}+\mathrm{b} \times$ time $+\mathrm{c} \times$ time $^{2}$ ) using PROC NLIN. Estimated overall emission lines were compared between treatments using the dummy variable regression technique (PROC NLMIXED; Bates and Watts, 1988).

Statistical differences were declared at $P<0.05$. Differences between treatments with $0.05 \leq P \leq 0.10$ were considered as a trend toward significance. Data are presented as least squares means.

\section{RESULTS}

\section{Exp. 1 and 2}

The EO treatment had no effect on rumen $\mathrm{pH}$, total free AA (Exp. 1), total VFA, acetate, propionate, butyrate, and valerate concentrations, or acetate to propionate ratio in Exp. 1, and no effect on protozoal counts and polysaccharide-degrading activities in Exp. 1 (Table 3). Acetate to propionate ratio tended to be decreased $(P=0.06)$ by EO in Exp. 2. Ruminal ammonia concentration was increased by $40 \%(P<0.001)$ for cows fed EO in Exp. 1, but treatment had no effect on ruminal ammonia concentration in Exp. 2. Isobutyrate (both Exp. 1 and 2) and isovalerate (Exp. 1 only) concentrations were increased $(P<0.001, P=0.04$, and $P=0.002$, respectively) by EO.

Dry matter intake, milk yield, and $3.5 \%$ FCM and FCM feed efficiency were unaffected by EO in Exp. 1 and 2 (Table 4). Feed efficiency was slightly increased $(P=0.009)$ in Exp. 1, but no effect of treatment was observed in Exp. 2. Milk fat, protein, and lactose concentrations were unaffected by treatment in either experiment. Milk protein and lactose yields tended to be slightly greater $(P=0.06)$ for $\mathrm{EO}$ in Exp. 1 , but not in Exp. 2. Concentration of MUN was increased $(P<0.001) 13 \%$ by EO in Exp. 1, but not in Exp. 2 . Secretion of milk $\mathrm{NE}_{\mathrm{L}}$ tended to be slightly greater $(P$ $=0.09$ ) with EO, compared with the control in Exp. 1, but not in Exp. 2.

Intake of DM (during the digestibility measurements) and dietary nutrients was not different between diets in Exp. 1 and 2 (Table 5). No difference was observed in apparent total-tract digestibility of nutrients in Exp. 1 and 2, except that NDF digestibility was increased $(P$ $=0.03)$ by EO in Exp. 1 and tended to be increased $(P$ $=0.07)$ in Exp. 2 .

Excretion of urinary purine derivatives was increased $(P \leq 0.03)$ by EO compared with the control in Exp. 1 , but not in Exp. 2 (Table 6 ). Urinary total, but not fecal, and urea $\mathrm{N}$ excretions were greater $(P \leq 0.02)$ for EO compared with the control in Exp. 1, which led to increased $(P \leq 0.003)$ total excreta losses with the former diet. Urinary and fecal excretion data did not differ between treatments in Exp. 2. Secretion of milk protein $\mathrm{N}$ tended to be slightly greater $(P=0.06)$ for EO than the control in Exp. 1, but was not different between treatments in Exp. 2. Plasma glucose concentrations of cows fed EO were not different from the control cows in Exp. 1 and 2 (average of $60 \pm 0.6$ and $65 \pm 3.0 \mathrm{mg} / \mathrm{dL} ; P=0.89$ and 0.29 , respectively; data not presented in tables). Cows fed the EO diet had greater $(P<0.001)$ PUN concentrations than the control cows in Exp. 1 and lower $(P=0.03)$ in Exp. 2.

Cumulative $(23 \mathrm{~h})$ ammonia emission from manure was greater $(P=0.03$, Figure 1$)$ for EO compared with the control in Exp. 1, whereas manure methane emission (Figure 2) was unaffected by treatment.

\section{Exp. 3}

Dry matter intake, 3.5\% FCM yield, milk composition, milk fat, protein, and lactose yields, feed efficiency, 
Table 3. Ruminal fermentation characteristics of dairy cows fed a control or an essential oil-supplemented diet in experiments (Exp.) 1 and $2^{1}$

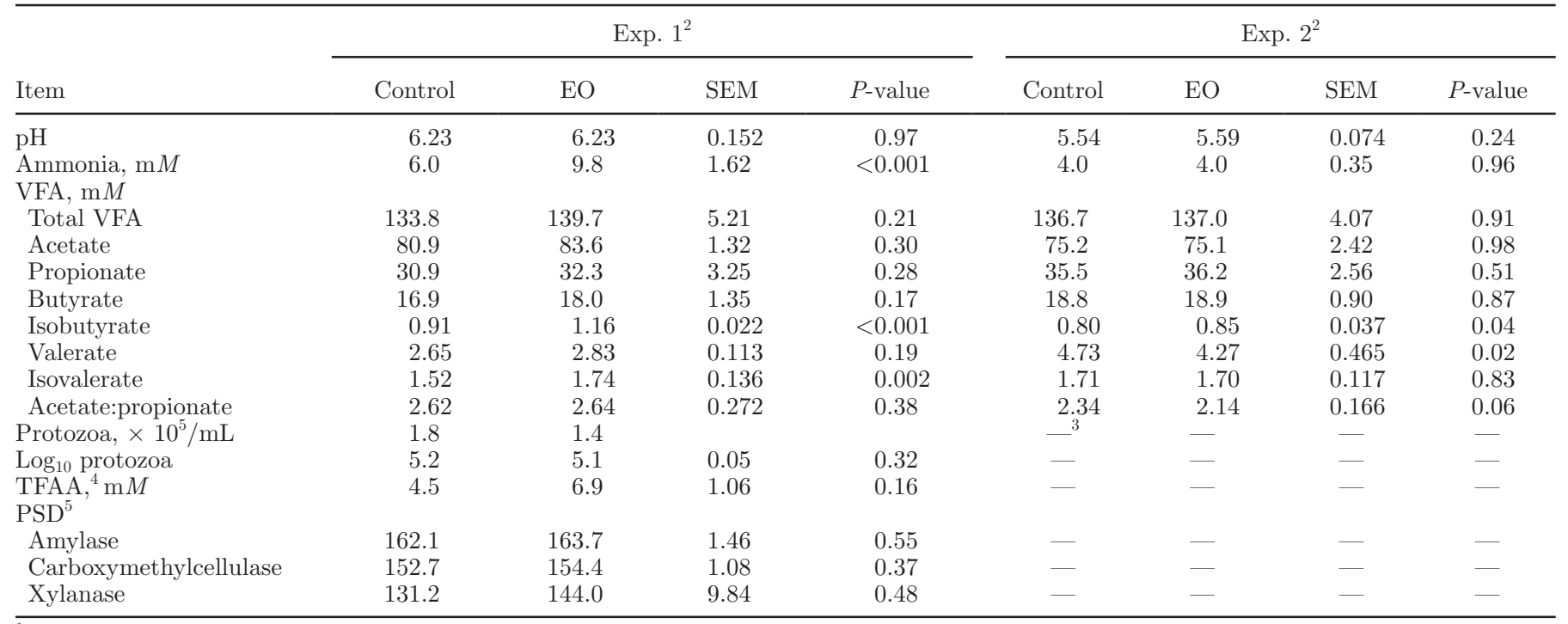

${ }^{1}$ LSM. Exp. 1: $\mathrm{pH}$, ammonia, and VFA, $\mathrm{n}=48 ; \mathrm{n}=8$ for the remaining variables. Exp. $2: \mathrm{n}=96$ ( $\mathrm{n}$ is the number of observations used in the statistical analysis).

${ }^{2}$ Control = unsupplemented ration; EO = essential oil-supplemented ration (Xtract 6965 fed at $525 \mathrm{mg} /$ cow per d; Pancosma SA, Geneva, Switzerland). In Exp. 1, Xtract 6965 was mixed with the mineral-vitamin premix by the manufacturer (Cargill Animal Nutrition, Cargill Inc., Roaring Spring, PA) and then mixed with the TMR and in Exp. 2, Xtract 6965 was top-dressed and mixed with a portion of the TMR before feeding.

${ }^{3}$ Not analyzed in Exp. 2.

${ }^{4} \mathrm{TFAA}=$ total free AA.

${ }^{5} \mathrm{PSD}=$ polysaccharide-degrading activities. Expressed as nanomoles of reducing sugars as glucose released per milliliter of ruminal fluid per minute.

and MUN concentration were unaffected by EO in Exp. 3 (Table 7). Milk yield tended to be slightly lower $(P=$ 0.08) for EO compared with the control.

\section{DISCUSSION}

With the exception of an increase in rumen concentrations of ammonia and the branched-chain VFA in 1 or 2 of the experiments, the EO blend tested in the current trials had no effects on rumen fermentation when fed at $525 \mathrm{mg} / \mathrm{d}$. The increase in rumen ammonia may be a result of elevated protein degradation or ammonia not being efficiently captured into microbial protein, but this effect was not consistent. The EO product was applied differently in Exp. 1 and 2. In Exp. 1, Xtract 6965 was included in the mineralvitamin premix and was exposed to potential reactions with premix ingredients. In Exp. 2, Xtract 6965 was directly applied to the TMR, immediately before feeding. To what extent, if any, these 2 application methods affected the results from Exp. 1 and 2 is unclear. Unlike ammonia, increased isobutyrate concentration in ruminal fluid was consistently observed with EO in both Exp. 1 and 2. Benchaar et al. (2012) also reported increased branched-chain VFA concentrations in dairy cows fed diets with 2 levels of concentrate (35 and 65\%) and supplemented with $50 \mathrm{mg} / \mathrm{kg}$ DM of eugenol. In the rumen, the branched-chain VFA are derived from branched-chain AA (Wolin et al., 1997). These results most likely reflect decreased branched-chain AA concentration in the rumen with EO caused by enhanced microbial uptake or decreased production.

The trend for slightly decreased acetate to propionate ratio in Exp. 2 is worth mentioning. Propionate is an important glucose precursor in ruminants (Wolin et al., 1997), and EO supplementation was beneficial in altering the ruminal fermentation in 1 of the 2 experiments with cannulated cows. Some constituents of EO (thymol, eugenol, cinnamaldehyde) have been reported to increase ruminal propionate concentration in vitro or in vivo (Calsamiglia et al., 2007). In the Benchaar et al. (2008) study, cinnamaldehyde had no effect on rumen $\mathrm{pH}$, ammonia, and total or individual VFA concentrations. Previous in vitro studies with the active compounds of Xtract 6965 , eugenol and cinnamaldehyde, reported decreased ammonia and increased propionate concentrations, but the inclusion levels were 3 to 300 times greater (Busquet et al., 2006) than those used in the current trials. Our observations are consistent with those from a recent trial with dairy cows, in which an 
Table 4. Dry matter intake, milk yield, milk composition, and BW of dairy cows fed a control or an essential oil-supplemented diet in experiments (Exp.) 1 and $2^{1}$

\begin{tabular}{|c|c|c|c|c|c|c|c|c|}
\hline \multirow[b]{2}{*}{ Item } & \multicolumn{4}{|c|}{ Exp. $1^{2}$} & \multicolumn{4}{|c|}{ Exp. $2^{2}$} \\
\hline & Control & $\mathrm{EO}$ & SEM & $P$-value & Control & $\mathrm{EO}$ & SEM & $P$-value \\
\hline Feed efficiency, ${ }^{3} \mathrm{~kg} / \mathrm{kg}$ & 1.52 & 1.56 & 0.057 & 0.009 & 1.63 & 1.59 & 0.058 & 0.25 \\
\hline Fat, $\%$ & 3.39 & 3.43 & 0.125 & 0.64 & 3.22 & 3.31 & 0.112 & 0.38 \\
\hline Fat, ${ }^{4} \mathrm{~kg} / \mathrm{d}$ & 1.41 & 1.45 & 0.056 & 0.22 & 1.37 & 1.42 & 0.069 & 0.38 \\
\hline Lactose, $\%$ & 4.81 & 4.81 & 0.058 & 0.96 & 4.87 & 4.84 & 0.046 & 0.35 \\
\hline Lactose ${ }^{4} \mathrm{~kg} / \mathrm{d}$ & 2.01 & 2.05 & 0.044 & 0.06 & 2.10 & 2.07 & 0.068 & 0.65 \\
\hline Milk urea N, mg/dL & 8.3 & 9.5 & 0.41 & $<0.001$ & 12.0 & 12.3 & 0.48 & 0.50 \\
\hline $\mathrm{SCC},{ }^{4} \times 10^{3}$ cells $/ \mathrm{mL}$ & 88 & 102 & 36.2 & 0.21 & 47 & 45 & 15.9 & 0.29 \\
\hline $3.5 \% \mathrm{FCM}^{4}{ }^{4} \mathrm{~kg} / \mathrm{d}$ & 41.0 & 42.1 & 1.22 & 0.12 & 40.3 & 41.0 & 1.51 & 0.55 \\
\hline FCM feed efficiency, ${ }^{5} \mathrm{~kg} / \mathrm{kg}$ & 1.50 & 1.54 & 0.051 & 0.23 & 1.53 & 1.52 & 0.051 & 0.87 \\
\hline Milk $\mathrm{NE}_{\mathrm{L}},{ }^{6} \mathrm{Mcal} / \mathrm{d}$ & 27.9 & 28.7 & 0.76 & 0.09 & 27.9 & 28.2 & 0.98 & 0.66 \\
\hline
\end{tabular}

${ }^{1}$ LSM. Exp. 1: DMI, milk yield, and feed efficiency, $\mathrm{n}=243$ to $280 ; \mathrm{n}=40$ for the remaining variables. Exp. 2: DMI, milk yield, and feed efficiency, $\mathrm{n}=264$ to $277 ; \mathrm{n}=40$ for the remaining variables ( $\mathrm{n}$ is the number of observations used in the statistical analysis).

${ }^{2}$ Control = unsupplemented ration; EO = essential oil-supplemented ration (Xtract 6965 fed at 525 mg/cow per d; Pancosma SA, Geneva, Switzerland). In Exp. 1, Xtract 6965 was mixed with the mineral/vitamin premix by the manufacturer (Cargill Animal Nutrition, Cargill Inc., Roaring Spring, PA) and then mixed with the TMR and in Exp. 2, Xtract 6965 was top-dressed and mixed with a portion of the TMR before feeding.

${ }^{3}$ Milk yield/DMI.

${ }^{4}$ Data not normally distributed (Shapiro-Wilk test, $\mathrm{W}<0.90$ ); statistical analysis performed on log-transformed data.

${ }^{5}$ Calculated based on milk yield, milk composition, and DMI during last week of each experimental period.

${ }^{6} \mathrm{NE}_{\mathrm{L}}=$ milk yield, $\mathrm{kg} / \mathrm{d} \times(0.0929 \times$ milk fat, $\%+0.0563 \times$ milk true protein, $\%+0.0395 \times$ milk lactose, $\%)$; based on NRC $(2001)$.

EO preparation similar to that used in the current trial (i.e., based on cinnamaldehyde and eugenol) and fed at $500 \mathrm{mg} / \mathrm{d}$ had no effect on ruminal VFA (Tager and Krause, 2011).
The slightly increased urinary PD excretion in cows receiving the EO supplement in Exp. 1 is interesting but was not repeated in Exp. 2. Increased urinary PD excretion is an indication of increased microbial protein

Table 5. Nutrient intakes and apparent total-tract digestibilities of dairy cows fed a control or an essential oil-supplemented diet in experiments (Exp.) 1 and $2^{1}$

\begin{tabular}{|c|c|c|c|c|c|c|c|c|}
\hline \multirow[b]{2}{*}{ Item } & \multicolumn{4}{|c|}{ Exp. $1^{2}$} & \multicolumn{4}{|c|}{ Exp. $2^{2}$} \\
\hline & Control & EO & SEM & $P$-value & Control & $\mathrm{EO}$ & SEM & $P$-value \\
\hline OM & 26.1 & 26.2 & 0.66 & 0.78 & 24.1 & 24.9 & 0.81 & 0.34 \\
\hline $\mathrm{N}$ & 0.67 & 0.67 & 0.017 & 0.70 & 0.61 & 0.63 & 0.020 & 0.36 \\
\hline $\mathrm{NDF}$ & 8.6 & 8.9 & 0.22 & 0.13 & 7.9 & 8.2 & 0.26 & 0.34 \\
\hline \multicolumn{9}{|c|}{ Apparent total-tract digestibility, $\%$} \\
\hline DM & 63.8 & 64.4 & 0.41 & 0.37 & 68.3 & 68.7 & 0.19 & 0.17 \\
\hline OM & 64.9 & 65.4 & 0.44 & 0.39 & 69.3 & 69.8 & 0.18 & 0.12 \\
\hline $\mathrm{N}$ & 59.3 & 59.2 & 0.60 & 0.95 & 61.3 & 61.6 & 0.82 & 0.65 \\
\hline NDF & 34.3 & 37.4 & 1.05 & 0.03 & 45.5 & 46.3 & 0.64 & 0.07 \\
\hline $\mathrm{ADF}$ & 29.6 & 30.5 & 1.36 & 0.59 & 41.1 & 41.4 & 0.73 & 0.74 \\
\hline TNC & 90.6 & 91.0 & 0.20 & 0.10 & - & - & - & - \\
\hline
\end{tabular}

${ }^{1} \mathrm{LSM} ; \mathrm{n}=40$ ( $\mathrm{n}$ is the number of observations used in the statistical analysis).

${ }^{2}$ Control = unsupplemented ration; EO = essential oil-supplemented ration (Xtract 6965 fed at $525 \mathrm{mg} /$ cow per d; Pancosma SA, Geneva, Switzerland). In Exp. 1, Xtract 6965 was mixed with the mineral/vitamin premix by the manufacturer (Cargill Animal Nutrition, Cargill Inc., Roaring Spring, PA) and then mixed with the TMR and in Exp. 2, Xtract 6965 was top-dressed and mixed with a portion of the TMR before feeding.

${ }^{3}$ Intake during the digestibility measurement period.

${ }^{4}$ Total nonstructural carbohydrates. Not analyzed in Exp. 2. 


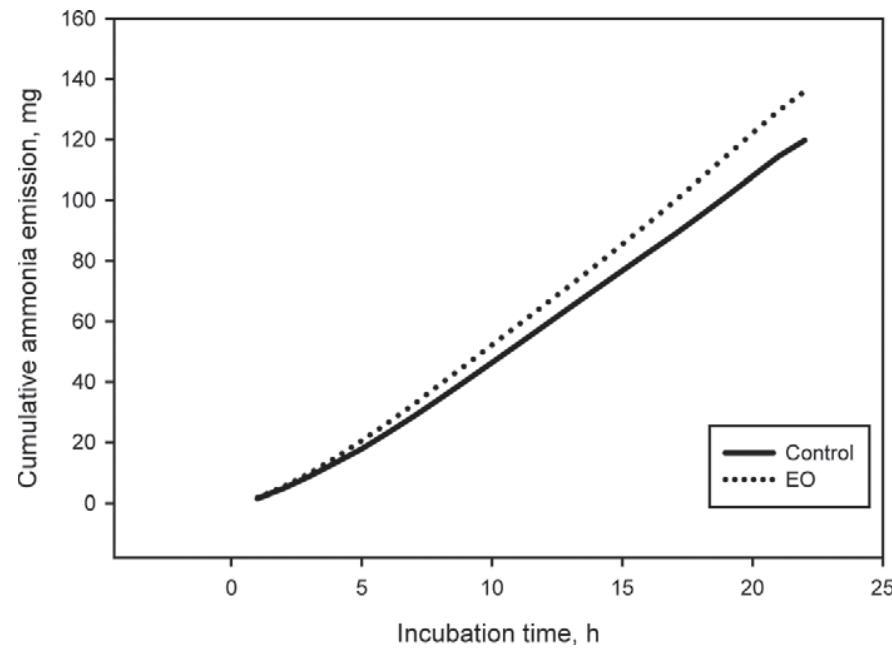

Figure 1. Cumulative ammonia emissions from manure from dairy cows fed a control or an essential oil (EO)-supplemented diet in experiment 1 (emission lines, $P=0.03$ ).

production in the rumen, and the effect observed in Exp. 1 could be a result of a combination of factors. Branched-chain VFA, for example, have been shown to promote bacterial growth in the rumen (Wolin et al., 1997). Other blends of EO also containing eugenol have resulted in no differences in microbial $\mathrm{N}$ flow when supplemented at $750 \mathrm{mg} / \mathrm{d}$ (Benchaar et al., 2007). Urinary PD are not a very reliable marker of microbial

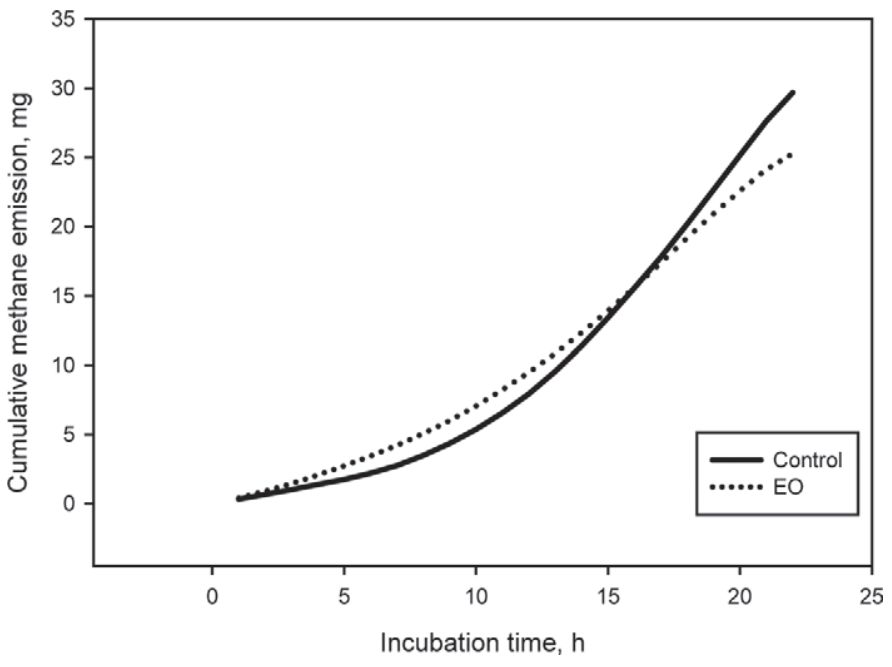

Figure 2. Cumulative methane emissions from manure from dairy cows fed a control or an essential oil (EO)-supplemented diet in experiment 1 (emission lines, $P=0.43$ ).

protein production in the rumen, usually resulting in over-prediction of microbial protein synthesis (Hristov et al., 2005; Reynal et al., 2005), but this should not affect comparative data as in the current study.

Production variables were unaffected by EO in these experiments, except feed efficiency, which was increased in Exp. 1, but not in Exp. 2 or 3. In other studies (Benchaar et al., 2006; Yang et al., 2007; Tassoul and

Table 6. Urinary purine derivatives (PD) and N excretion and secretion in dairy cows fed a control or an essential oil-supplemented diet in experiments (Exp.) 1 and $2^{1}$

\begin{tabular}{|c|c|c|c|c|c|c|c|c|}
\hline \multirow[b]{2}{*}{ Item } & \multicolumn{4}{|c|}{ Exp. $1^{2}$} & \multicolumn{4}{|c|}{ Exp. $2^{2}$} \\
\hline & Control & $\mathrm{EO}$ & SEM & $P$-value & Control & EO & SEM & $P$-value \\
\hline Allantoin & 681 & 713 & 18.8 & 0.03 & 625 & 618 & 27.9 & 0.69 \\
\hline Uric acid & 75 & 80 & 3.9 & 0.005 & 61 & 57 & 2.9 & 0.22 \\
\hline Total PD & 756 & 793 & 20.5 & 0.02 & 686 & 675 & 31.3 & 0.58 \\
\hline \multicolumn{9}{|l|}{ Urinary and fecal excretions } \\
\hline Urine $\mathrm{N}, \%$ of $\mathrm{N}$ intake & 23.4 & 29.9 & 1.33 & 0.002 & 23.0 & 22.0 & 1.53 & 0.48 \\
\hline Fecal N, kg/d & 0.271 & 0.275 & 0.0069 & 0.59 & 0.237 & 0.242 & 0.0123 & 0.60 \\
\hline Fecal N, \% of $\mathrm{N}$ intake & 40.7 & 40.8 & 0.60 & 0.95 & 38.7 & 38.4 & 0.82 & 0.65 \\
\hline Urinary and fecal $\mathrm{N}$ excretion, $\mathrm{kg} / \mathrm{d}$ & 0.425 & 0.472 & 0.0075 & $<0.001$ & 0.374 & 0.379 & 0.0089 & 0.72 \\
\hline Urinary and fecal $\mathrm{N}$ excretion, $\%$ of $\mathrm{N}$ intake & 64.1 & 70.7 & 1.48 & 0.003 & 61.7 & 60.6 & 0.88 & 0.46 \\
\hline Urea $\mathrm{N}, \mathrm{g} / \mathrm{d}$ & 79.1 & 107.1 & 3.92 & $<0.001$ & 65.4 & 68.1 & 3.42 & 0.56 \\
\hline Urea $\mathrm{N}, \%$ of urine $\mathrm{N}$ & 51.7 & 54.8 & 1.44 & 0.21 & 46.9 & 49.7 & 1.98 & 0.47 \\
\hline
\end{tabular}

${ }^{1} \mathrm{LSM} ; \mathrm{n}=40$ ( $\mathrm{n}$ is the number of observations used in the statistical analysis).

${ }^{2}$ Control = unsupplemented ration; EO = essential oil-supplemented ration (Xtract 6965 fed at $525 \mathrm{mg} / \mathrm{cow}$ per d; Pancosma SA, Geneva, Switzerland). In Exp. 1, Xtract 6965 was mixed with the mineral/vitamin premix by the manufacturer (Cargill Animal Nutrition, Cargill Inc., Roaring Spring, PA) and then mixed with the TMR and in Exp. 2, Xtract 6965 was top-dressed and mixed with a portion of the TMR before feeding.

${ }^{3} \mathrm{PUN}=$ plasma urea N. Exp. 2, blood samples were collected from only 8 cows in period 2 (i.e., $\mathrm{n}=8$ ). 
Table 7. Dry matter intake, feed efficiency, milk yield, and milk composition of dairy cows fed a control or an essential oil-supplemented diet in experiment (Exp.) $3^{1,2}$

\begin{tabular}{lcccc}
\hline Item & Control & EO & SEM & $P$-value \\
\hline DMI, kg/d & 28.5 & 28.7 & 0.36 & 0.87 \\
Milk, kg/d & 35.9 & 35.2 & 0.61 & 0.08 \\
Feed efficiency, kg/kg & 1.26 & 1.23 & 0.031 & 0.54 \\
Milk fat, \% & 3.81 & 3.80 & 0.109 & 0.92 \\
Milk fat, kg/d & 1.39 & 1.33 & 0.033 & 0.34 \\
Milk protein, \% & 3.09 & 3.08 & 0.020 & 0.81 \\
Milk protein, kg/d & 1.11 & 1.09 & 0.030 & 0.66 \\
Milk lactose, \% & 4.72 & 4.75 & 0.012 & 0.32 \\
Milk lactose, kg/d & 1.72 & 1.66 & 0.057 & 0.54 \\
MUN, mg/dL & 11.3 & 10.9 & 0.24 & 0.39 \\
SCC, ${ }^{3} \times 0^{3}$ cells/mL & 164 & 123 & 18.3 & 0.25 \\
$3.5 \%$ FCM, kg/d & 38.6 & 36.3 & 0.77 & 0.16 \\
$3.5 \%$ FCM feed efficiency, kg/kg & 1.32 & 1.31 & 0.026 & 0.90 \\
Milk NE ${ }_{L}^{4}$ Mcal/d & 25.9 & 25.1 & 0.66 & 0.47 \\
Milk NE ${ }_{\mathrm{L}}$ feed efficiency, Mcal/kg & 0.89 & 0.90 & 0.025 & 0.93 \\
\hline
\end{tabular}

${ }^{1}$ Covariate-adjusted means: $\mathrm{n}=341$ to 356 for DMI, milk yield, and feed efficiency; $\mathrm{n}=6$ for milk composition, $\mathrm{FCM}$, and milk $\mathrm{NE}_{\mathrm{L}}$ variables ( $\mathrm{n}$ is the number of observations used in the statistical analysis).

${ }^{2}$ Control = unsupplemented ration; EO = essential oil-supplemented ration (Xtract 6965 fed at $525 \mathrm{mg} / \mathrm{cow}$ per d; Pancosma SA, Geneva, Switzerland). In Exp. 1, Xtract 6965 was mixed with the mineral/vitamin premix by the manufacturer (Cargill Animal Nutrition, Cargill Inc., Roaring Spring, PA) and then mixed with the TMR and in Exp. 2, Xtract 6965 was top-dressed and mixed with a portion of the TMR before feeding.

${ }^{3}$ Averaged per pen data were normally distributed (Shapiro-Wilk test, $\mathrm{W}>0.90$ ).

${ }^{4} \mathrm{NE}_{\mathrm{L}}=$ milk yield, $\mathrm{kg} / \mathrm{d} \times(0.0929 \times$ milk fat, $\%+0.0563 \times$ milk true protein, $\%+0.0395 \times$ milk lactose, $\%)$; based on NRC (2001).

Shaver, 2009; Santos et al., 2010; Tager and Krause, 2011), production responses to essential oil and herbal supplementation have been limited and variable. Tager and Krause (2011) reported no effect of EO on cow productivity. Other published research has investigated the individual EO constituents of Xtract 6965 or other blends of active EO compounds. Benchaar et al. (2008), for example, evaluated supplementing $1 \mathrm{~g} / \mathrm{d}$ of cinnamaldehyde to a lactating cow diet and reported no effects on milk production, $4.0 \%$ FCM, MUN, SCC, or milk fat and protein content and yields. A later trial from the same group reported no difference in milk production or composition when supplementing eugenol at 50 $\mathrm{mg} / \mathrm{kg}$ of dietary DM (Benchaar et al., 2012). Santos et al. (2010) observed increased milk fat content and yield with an EO mixture containing eugenol, geranyl acetate, and coriander oil, which only further emphasizes the extreme variability in animal responses to EO and their active ingredients.

The EO product investigated in the current experiments had no effect on intake and digestibility of most nutrients. Total-tract digestibility of NDF, however, was consistently increased or tended to be increased in 2 experiments with a total of 40 cows. A similar product produced no such effect in the study by Tager and Krause (2011), although total-tract digestibility of all nutrients in that study was unrealistically low (explained by the authors by the small particle size of the TMR fed). Variability was also large in the latter study, which rendered a difference of over 5 percentage units in NDF digestibility between treatments. In prior in vitro research, decreased nutrient digestibility has been observed at high inclusion levels of EO, which may have resulted from the antibacterial properties of these compounds. Benchaar et al. (2008) reported no effect on DMI or digestibility when supplementing lactating dairy cows with $1 \mathrm{~g} / \mathrm{d}$ of cinnamaldehyde. Castillejos et al. (2006) evaluated the addition of 5, 50, and $500 \mathrm{mg} / \mathrm{L}$ of eugenol in a continuous-culture fermenter and reported no effects on DM, NDF, and ADF digestibility. Digestibility of nutrients was also unaffected by the addition of a blend of EO that contained eugenol in several in vivo trials at various inclusion rates (Benchaar et al., 2006, 2007), or with other EO (Santos et al., 2010). The increased NDF digestibility in the current trials was not related to any ruminal fermentation effects or animal productivity. The lack of response in animal productivity to increased dietary NDF digestibility is not surprising and is likely due to the small magnitude of the digestibility effect and the apparent oversupply of dietary energy to the cows in both Exp. 1 and 2.

The increased PUN concentration with EO in Exp. 1 could be attributed to the increased ammonia concentration in the rumen (Wilson et al., 1998). Consequently, increased PUN levels are likely to result in increased MUN (Broderick and Clayton, 1997), as observed in Exp. 1. These effects, however, were not observed in 
Exp. 2. Average rumen $\mathrm{pH}$ was considerably lower in Exp. 2 compared with Exp. 1 and it is unclear if this had any effect on the fermentation variables in Exp. 2. Other studies investigating eugenol-based blends of EO (supplemented at $2 \mathrm{~g} / \mathrm{d}$ or $750 \mathrm{mg} / \mathrm{d}$; Crina, Crina S.A., Gland, Switzerland) reported no differences in N retention (Benchaar et al., 2006, 2007). Milk urea $\mathrm{N}$ concentration was unaffected in Exp. 3, which was in contrast to the results from Exp. 1 (these experiments were conducted concurrently). This discrepancy is difficult to explain. Rumen fermentation was not monitored in Exp. 3 and information on ruminal ammonia concentration (or blood metabolites) is not available. Cows in Exp. 3 had lower milk production than cows in Exp. 1, which may have affected their $\mathrm{N}$ requirements and liver urea production, PUN levels, and ruminal urea recycling. Diets in Exp. 1 and 3 had similar protein levels and composition. Cows in Exp. 3 , however, had numerically lower milk protein output at similar $\mathrm{N}$ intake to Exp. 1, which likely resulted in less-efficient utilization of recycled urea (reflected in greater MUN concentrations) compared with Exp. 1. This demand-supply relationship may have resulted in the lack of effect of EO on $\mathrm{N}$ metabolism and eventually MUN concentration in Exp. 3. Similar mechanisms may help explain the discrepancy in milk protein (or fat) yield responses to EO between Exp. 1 and 3. This explanation, however, does not hold for Exp. 2.

The EO product increased cumulative ammonia emission from manure in Exp. 1. The dominant factor affecting ammonia emissions from manure is the quantity of urinary N excreted (Ndegwa et al., 2008; Agle et al., 2010). Thus, the elevated ammonia-emitting potential of manure from the EO cows can logically be explained by the increased urinary urea $\mathrm{N}$ excretion with the EO treatment. In Exp. 1, fecal concentrations of N, NDF, and total nonstructural carbohydrates were unaffected by the EO treatment. As manure methane emissions are primarily a result of fermentation of available substrate (Massé et al., 2008), it is not surprising that the methane-emitting potential of manure did not differ between treatments.

\section{CONCLUSIONS}

In 3 experiments, diets supplemented with an EO product based on eugenol and cinnamaldehyde had no or only marginal effects on milk production and composition in dairy cows. Ruminal concentrations of branched-chain VFA increased with EO supplementation in 2 trials, but no other consistent effects on ruminal fermentation were observed. Total-tract digestibility of NDF was increased or tended to be increased with EO in 2 experiments. In 1 trial, urinary $\mathrm{N}$ losses and manure ammonia emissions were increased by EO. Overall, results from these studies indicate marginal effects of the tested EO product fed at $525 \mathrm{mg} / \mathrm{d}$ on ruminal fermentation and productivity of lactating dairy cows but do show a trend for a consistent increase in total-tract NDF digestibility.

\section{ACKNOWLEDGMENTS}

The authors thank the staff of the Department of Animal Science Dairy Center (The Pennsylvania State University, University Park) for their conscientious care of the experimental cows.

\section{REFERENCES}

Agle, M., A. N. Hristov, S. Zaman, C. Schneider, P. Ndegwa, and V. K. Vaddella. 2010. Effects of ruminally degraded protein on rumen fermentation and ammonia losses from manure in dairy cows. J. Dairy Sci. 93:1625-1637.

AOAC International. 2005. Official Methods of Analysis. 18th ed. AOAC International, Arlington, VA.

Bates, D. M., and D. G. Watts. 1988. Nonlinear Regression Analysis and Its Applications. John Wiley \& Sons, New York, NY.

Benchaar, C., A. N. Hristov, and H. Greathead. 2009. Essential oils as feed additives in ruminant nutrition. Pages 111-146 in Phytogenics in Animal Nutrition: Natural Concepts to Optimize Gut Health and Performance. T. Steiner, ed. Nottingham University Press, Nottingham, UK

Benchaar, C., A. Lettat, F. Hassanat, W. Z. Yang, R. J. Forster, H. V. Petit, and P. Y. Chouinard. 2012. Eugenol for dairy cows fed low or high concentrate diets: Effects on digestion, ruminal fermentation characteristics, rumen microbial populations and milk fatty acid profile. Anim. Feed Sci. Technol. 178:139-150.

Benchaar, C., T. A. McAllister, and P. Y. Chouinard. 2008. Digestion, ruminal fermentation, ciliate protozoal populations, and milk production from dairy cows fed cinnamaldehyde, quebracho condensed tannin, or Yucca schidigera saponin extracts. J. Dairy Sci. 91:4765-4777.

Benchaar, C., H. V. Petit, R. Berthiaume, D. R. Ouellet, J. Chiquette, and P. Y. Chouinard. 2007. Effects of essential oils on digestion, ruminal fermentation, rumen microbial populations, milk production, and milk composition in dairy cows fed alfalfa silage or corn silage. J. Dairy Sci. 90:886-897.

Benchaar, C., H. V. Petit, R. Berthiaume, T. D. Whyte, and P. Y. Chouinard. 2006. Effects of addition of essential oils and monensin premix on digestion, ruminal fermentation, milk production, and milk composition in dairy cows. J. Dairy Sci. 89:4352-4364.

Broderick, G. A., and M. K. Clayton. 1997. A statistical evaluation of animal and nutritional factors influencing concentrations of milk urea nitrogen. J. Dairy Sci. 80:2964-2971.

Busquet, M., S. Calsamiglia, A. Ferret, and C. Kamel. 2006. Plant extracts affect in vitro rumen microbial fermentation. J. Dairy Sci. 89:761-771.

Calsamiglia, S., M. Busquet, P. W. Cardozo, L. Castillejos, and A. Ferret. 2007. Invited review: Essential oils as modifiers of rumen microbial fermentation. J. Dairy Sci. 90:2580-2595.

Castillejos, L., S. Calsamiglia, and A. Ferret. 2006. Effect of essential oils active compounds on rumen microbial fermentation and nutrient flow in in vitro systems. J. Dairy Sci. 89:2649-2658.

Chao, S. C., and D. G. Young. 2000. Screening for inhibitory activity of essential oils on selected bacteria, fungi and viruses. J. Essent. Oil Res. 12:639-649.

Hristov, A. N., C. Lee, T. Cassidy, M. Long, B. Corl, and R. Forster. 2011. Effects of lauric and myristic acids on ruminal fermentation, production, and milk fatty acid composition in lactating dairy cows. J. Dairy Sci. 94:382-395. 
Hristov, A. N., C. Lee, R. A. Hristova, P. Huhtanen, and J. Firkins. 2012. A meta-analysis of the variability in continuous culture rumen fermentation and digestibility data. J. Dairy Sci. 95:52995307.

Hristov, A. N., T. A. McAllister, D. R. Ouellet, and G. A. Broderick. 2005. Comparison of purines and nitrogen-15 as microbial flow markers in beef heifers fed barley- or corn-based diets. Can. J. Anim. Sci. 85:211-222.

Huhtanen, P., K. Kaustell, and S. Jaakkola. 1994. The use of internal markers to predict total digestibility and duodenal flow of nutrients in cattle given six different diets. Anim. Feed Sci. Technol. 48:211-227.

Kung, L. Jr., P. Williams, R. J. Schmidt, and W. Hu. 2008. A blend of essential plant oils used as an additive to alter silage fermentation or used as a feed additive for lactating dairy cows. J. Dairy Sci. 91:4793-4800.

Lee, C., A. N. Hristov, C. J. Dell, G. W. Feyereisen, J. Kaye, and D. Beegle. 2012. Effect of dietary protein concentration on ammonia and greenhouse gas emissions from dairy manure. J. Dairy Sci. 95:1930-1941.

Lee, C., A. N. Hristov, K. S. Hyler, T. W. Cassidy, M. Long, B. A. Corl, and S. K. R. Karnati. 2011. Effects of dietary protein concentration and coconut oil supplementation on nitrogen utilization and production in dairy cows. J. Dairy Sci. 94:5544-5557.

Massé, D. I., L. Masse, S. Claveau, C. Benchaar, and O. Thomas. 2008. Methane emissions from manure storages. Trans. ASABE 51:1775-1781.

Ndegwa, P. M., A. N. Hristov, J. Arogo, and R. E. Sheffield. 2008. A review of ammonia emissions mitigation techniques for concentrated animal feeding operations. Biosystems Eng. 100:453-469.

NRC. 2001. Nutrient Requirements of Dairy Cattle. 7th rev. ed. National Academies Press, Washington, DC.

Reynal, S. M., G. A. Broderick, and C. Bearzi. 2005. Comparison of four markers for quantifying microbial protein flow from the rumen of lactating dairy cows. J. Dairy Sci. 88:4065-4082.
Santos, M. B., P. H. Robinson, P. Williams, and R. Losa. 2010. Effects of addition of an essential oil complex to the diet of lactating dairy cows on whole tract nutrient digestion and productive performance. Anim. Feed Sci. Technol. 157:64-71.

Schneider, B. H., and W. P. Flatt. 1975. The Evaluation of Feeds Through Digestibility Experiments. University of Georgia Press, Athens.

Smith, D. 1981. Removing and analyzing carbohydrate from plant tissue. Rep. No. R2107. Wisconsin Agric. Exp. Stn., Madison.

Tager, L. R., and K. M. Krause. 2011. Effects of essential oils on rumen fermentation, milk production, and feeding behavior in lactating dairy cows. J. Dairy Sci. 94:2455-2464.

Tassoul, M. D., and R. D. Shaver. 2009. Effect of a mixture of supplemental dietary plant essential oils on performance of periparturient and early lactation dairy cows. J. Dairy Sci. 92:1734-1740.

Van Soest, P. J., J. B. Robertson, and B. A. Lewis. 1991. Methods for dietary fiber, neutral detergent fiber, and nonstarch polysaccharides in relation to animal nutrition. J. Dairy Sci. 74:3583-3597.

Wallace, R. J. 2004. Antimicrobial properties of plant secondary metabolites. Proc. Nutr. Soc. 63:621-629.

Wilson, R. C., T. R. Overton, and J. H. Clark. 1998. Effects of Yucca schidigera extract and soluble protein on performance of cows and concentrations of urea nitrogen in plasma and milk. J. Dairy Sci. 81:1022-1027.

Wolin, M. J., T. L. Mikker, and C. S. Steward. 1997. Microbe-microbe interactions. Pages 467-491 in The Rumen Microbial Ecosystem. P. N. Hobson and C. S. Steward, ed. Blackie Academic and Professional, London, UK.

Yang, W. Z., C. Benchaar, B. N. Ametaj, A. V. Chaves, M. L. He, and T. A. McAllister. 2007. Effects of garlic and juniper berry essential oils on ruminal fermentation and on the site and extent of digestion in lactating cows. J. Dairy Sci. 90:5671-5681. 